\title{
Assessment of heavy metal concentrations in periwinkle (Tympanotonus fuscatus) samples from Uta ewa creek, Imo river estuary, South eastern Nigeria
}

\begin{abstract}
Heavy metal (HM) contents in periwinkle from Uta Ewa creek, Imo river estuary, Southeastern Nigeria were investigated. Samples were collected from the offshore landing fisher folks during July-November 2018. HM was determined using atomic absorption spectrophotometer-varian model spectral AA 220. The concentration values of cadmium were ranged from 0.59 to $0.935 \mathrm{mg} / \mathrm{kg}$ ( $\mathrm{mean} \pm \mathrm{SD}=0.68 \pm 0.13 \mathrm{mg} / \mathrm{kg}$ ), chromium from 0.31 to $0.82 \mathrm{mg} / \mathrm{kg}$ (mean $\pm \mathrm{SD}=0.60 \pm 0.26 \mathrm{mg} / \mathrm{kg}$ ), copper from 2.02 to $2.37 \mathrm{mg} / \mathrm{kg}$ (mean $\pm \mathrm{SD}=2.27 \pm 0.14 \mathrm{mg} / \mathrm{kg}$ ), iron from 1.83 to $3.03 \mathrm{mg} / \mathrm{kg}$ (mean $=2.36 \pm 0.51 \mathrm{mg} / \mathrm{kg}$ ), $\mathrm{Pb}$ from 0.02 to $0.22 \mathrm{mg} / \mathrm{kg}$ (mean $\pm \mathrm{SD}=0.13 \pm 0.94 \mathrm{mg} / \mathrm{kg}$ ), Manganese from 1.03 to $0.22 \mathrm{mg} / \mathrm{kg}$ (mean $\pm \mathrm{SD}=0.13 \pm 0.073 \mathrm{mg} / \mathrm{kg}$ ) and zinc from 1.08 to $2.29 \mathrm{mg} / \mathrm{kg}(\mathrm{mean} \pm \mathrm{SD}=1.70 \pm 0.50 \mathrm{mg}$ ) $\mathrm{kg}$ ). The results showed that concentrations of $\mathrm{Cd}, \mathrm{Cr}, \mathrm{Fe}, \mathrm{Mn}$ and $\mathrm{Zn}$ were higher in periwinkle than other metals $(\mathrm{Cu}$ and $\mathrm{Pb})$ determined, the values of which were opposed to the FEPA (Federal Environmental Protection Agency) and WHO (World Health Organization) permissible limits for ingestion of this aquatic resource. There were no significant variations recognized among the monthly accumulation of metals by the species. The results obtained from the present study revealed an evidence of the periwinkle fauna to bio-concentrate these heavy metals.
\end{abstract}

Keywords: Heavy metals, fauna, bio-accumulation, variations
Volume 9 Issue 2 - 2020

\author{
Nsikak O Abiaobo,' IdopiseAbasi E Asuquo² \\ 'Department of Zoology, Akwa Ibom State University, Nigeria \\ ${ }^{2}$ Department of Fisheries and Aquaculture, Akwa lbom State \\ University, Nigeria
}

Correspondence: IdopiseAbasi E Asuquo, Department of Fisheries and Aquaculture,Akwa Ibom State University, Nigeria, Email idopieabasi@yahoo.com

Received: February I5, 2020 | Published: March I8, 2020

\section{Introduction}

Heavy metals are generally defined as metals with relatively high densities, atomic weights, or atomic numbers. They are substances with high electrical conductivity, malleability and luster, which voluntarily lose their electrons to form cations (Khlifi and Hamzachaffai, 2010). Heavy metals are generally referred to as those metals, which possess specific density of more than $5 \mathrm{~g} / \mathrm{cm}^{3}$. Heavy metals are an important group of chemical pollutants whereby food and water is the main route for entry into our body. ${ }^{2}$ The pollution of the aquatic environment with heavy metals has become a worldwide problem and of scientific concern because these are not degradable and most of them have toxic effects on organisms. ${ }^{3,4}$ Heavy metals enter rivers and lakes from a variety of sources that include the rocks and soils directly exposed to surface water, in addition to the discharge of various treated and untreated liquid wastes to the water bodies. ${ }^{5,6}$ Examples of heavy metals are: arsenic(As), cadmium $(\mathrm{Cd})$, chromium $(\mathrm{Cr})$, cobalt $(\mathrm{Co})$, lead $(\mathrm{Pb})$ manganese $(\mathrm{Mn})$, mercury $(\mathrm{Hg})$, nickel $(\mathrm{Ni})$, thallium(Ti) and zinc $(\mathrm{Zn})$, which have a particular significance in ecotoxicology, since they are highly persistent. ${ }^{7}$ Toxicity is realized when these heavy metal levels are higher than the recommended limit, which is different for individual element in drinking water. The sources of heavy metals include weathering of rocks, a variety of anthropogenic activities that are affected by seasons; increase the concentrations of these heavy metals. ${ }^{8}$

Tympanotonus fuscatus, commonly known as periwinkle, is a brackish gastropod belonging to the family Potamididae. It is small and is characterized by turreted granular and spiny shell with a tapering end. This organism is endemic in Nigeria and West Africa. Despite the numerous benefits derived from Tympanotonus fuscatus, its sustainability is threatened by human activities as a result of urbanization. Humans in quest for development have over time, reduced the habitat of this organism through land reclamation for housing, crop farming and industries. These organisms accumulate most of the contaminants at much higher levels than those found in the water column and they are representative of the pollution of an area, hence can be used to monitor the quality of coastal waters. The gastropods have long been regarded as promising bio-indicators and bio-monitoring subjects. They are abundant in many brackish aquatic ecosystems as in the Niger Delta, being easily available for collection. They are highly tolerant to many pollutants and particularly exhibit high accumulation of heavy metals. It is therefore necessary to access and determine heavy metal concentration in the flesh tissues of periwinkle (Tympanotonus fuscatus) in line with permissible limits of FEPA and WHO.

\section{Materials and methods}

\section{Description of the study area}

Uta Ewa Creek is a tributary of Imo river that receives effluents from Aluminum Smelter Company (ALSCON) in Ikot Abasi, Akwa Ibom State, and is located at a distance of 4 miles from the creek. Ikot Abasi is located between longitude $7^{\circ}$ and $30^{\circ} \mathrm{E}$ and $7^{\circ}$ and $45^{\prime} \mathrm{E}$, and latitude $4^{\circ}$ and $30^{\circ} \mathrm{W}$ and $4^{\circ}$ and $45^{\circ} \mathrm{N}$. It is one of the local government areas of Akwa Ibom State, located within the coastal area of Niger delta region of Nigeria. It has a climate that can be differentiated into two seasons; the wet (raining) season begins in April and ends October, having an average annual rainfall varying between $2000 \mathrm{~mm}$ to $3500 \mathrm{~mm}$ Iyamba, 2004 and dry season, which begins in November and ends in March. The occupation of the people are fishing and farming, and the area is a semi-rural community in which the inhabitants depend mainly on rain and surface water as the 
only source of drinking and for domestic purposes. The major source of protein in the area is sea foods (fish, crabs, crayfish, clams and periwinkle). The effluent from Aluminum Smelter Plant and domestic waste water from Housing Estates (Ferrostal camp, Sweato camp, Worker's camp, Berger's camp and ALSCON Camp) in Ikot Abasi are discharged into this creek.

\section{Sample collection}

Samples of periwinkle (Tympanotonus fuscatus) used for the analysis were bought from the fisher who collected from where the fish were caught from Uta-ewa creek. The samples were thoroughly washed with the sea water, placed in separate labeled cellophane bags and preserved in ice cooled box. The samples were later transported to the Zoology Unit Laboratory, Department of Biological Sciences, Akwa Ibom State University and stored in the freezer at $-10^{\circ} \mathrm{C}$ prior to laboratory analysis. Sampling was carried out between July and November.

\section{Sample preparation}

The total length (TL) and the aperture length (AL) were measured to the nearest $0.0 \mathrm{~cm}$ using measuring board. The total weight of the periwinkle (TW) was measured by weighing with an electronic mettler balance. The soft part of the periwinkle was obtained by cracking the shell. The weight of the soft tissue of periwinkle was obtained by weighing with an electronic mettler balance and then placed on a foil paper and oven dried at $80^{\circ} \mathrm{C}$ for $24 \mathrm{~h}$ to obtain a dry tissue. The dried tissue was ground to a powder form with a ceramic mortar and pestle, sieved to obtain a uniform particle size using $2 \mathrm{~mm}$ mesh size and preserved in a well labeled plastic bottle indicating each month.

\section{Digestion procedure}

Dry tissue samples of periwinkle weighing $0.5 \mathrm{~g}$ were digested with $0.5 \mathrm{ml}$ of concentrated nitric acid $\left(\mathrm{HNO}_{3}\right)$. The digestion was carried out in a fume cupboard and water bath were switch on to stabilize and attain $100^{\circ} \mathrm{C}$ using a water bath. The completely digested samples were filtered through what-man filter paper and diluted to $100 \mathrm{ml}$ in a standard volumetric flask with distilled water. It was analyzed in Atomic Absorption Spectrophotometer (AAS). ${ }^{9}$

\section{Metal determination and AAS condition}

The resulting solutions were analyzed for metals using Atomic Absorption Spectrophotometer equipped with MS Window application software. The AAS determines the presence and concentration of metals such as from a liquid sample. The AAS instrument looks for a particular metal by use of ultra-violet light (UV Light). When the sample of interest is aspirated into a flame, any metal present in the sample absorbs some of the light thus reducing its intensity. The

instrument measures the change in intensity into an absorbance. As concentration goes up, absorbance goes up as well. AAS has high sensitivity which means that solution with concentration as low as part per million (PPM) range can be analyzed.

\section{Statistical analysis}

Data collected from the experiment were subjected to one-way analysis of variance (ANOVA), and student's t-test was used to assess whether samples varied significantly. Possibilities less than 0.05 $(p<0.05)$ were considered as statistically significant.

\section{Results}

The meanmonthlyheavymetal concentrations in periwinkle ( $\mathrm{mg} / \mathrm{kg}$ ) is shown in Table 1, monthly variations in heavy metals concentration $(\mathrm{mg} / \mathrm{kg})$ is shown in Table 2, total concentration, mean \pm standard deviation, and range of heavy metals $(\mathrm{mg} / \mathrm{mg})$ is shown in Table 3 and monthly total concentration $(\mathrm{mg} / \mathrm{kg}$ ) of heavy metals $\backslash$, mean \pm standard deviation and range is shown in Table 4 . The concentration of cadmium ranged from 0.59 to $0.94 \mathrm{mg} / \mathrm{kg}$ (mean $\pm \mathrm{SD}=0.68 \pm 0.132$ $\mathrm{mg} / \mathrm{kg}$ ), chromium from 0.31 to $0.82 \mathrm{mg} / \mathrm{kg}$ (mean $\pm \mathrm{SD}=0.60 \pm 0.26)$, copper from 2.02 to $2.37 \mathrm{mg} / \mathrm{kg}$ (mean $\pm \mathrm{SD}=2.27 \pm 0.14 \mathrm{mg} / \mathrm{kg}$ ), iron from 1.83 to $3.02 \mathrm{mg} / \mathrm{kg}$ (mean $\pm \mathrm{SD}=2.36 \pm 0.51 \mathrm{mg} / \mathrm{kg}$ ), $\mathrm{Pb}$ from 0.02 to $0.22 \mathrm{mg} / \mathrm{kg}($ mean $\pm \mathrm{SD}=0.13 \pm 0.94 \mathrm{mg} / \mathrm{kg})$, manganese from 1.03 to $0.22 \mathrm{mg} / \mathrm{kg}$ (mean $\pm \mathrm{SD}=0.13 \pm 0.07 \mathrm{mg} / \mathrm{kg}$ ), and the mean concentration of Zinc ranged from 1.083 to $2.292 \mathrm{mg} / \mathrm{kg}$ (mean $=1.70 \pm 0.50 \mathrm{mg} / \mathrm{kg}$ ).

Table I Monthly mean heavy metal concentration in periwinkle $(\mathrm{mg} / \mathrm{kg})$

\begin{tabular}{llllll}
\hline Months & Sum & Mean & SD & Min & Max \\
\hline July & 7.86 & 1.12 & 0.81 & 0.02 & 2.32 \\
August & 8.88 & 1.26 & 0.76 & 0.21 & 2.36 \\
September & 8.10 & 1.15 & 0.73 & 0.04 & 2.09 \\
October & 9.96 & 1.42 & 1.11 & 0.20 & 3.01 \\
November & 9.68 & 1.38 & 1.00 & 0.18 & 2.80 \\
\hline
\end{tabular}

Table 2 Monthly variations in heavy metals concentration $(\mathrm{mg} / \mathrm{kg})$ in periwinkle

\begin{tabular}{llllllll}
\hline Months & $\mathbf{C d}$ & $\mathbf{C r}$ & $\mathbf{C u}$ & $\mathbf{F e}$ & $\mathbf{P b}$ & $\mathbf{M n}$ & $\mathbf{Z n}$ \\
\hline July & 0.59 & 0.73 & 2.32 & 2.07 & 0.02 & 1.03 & 1.08 \\
August & 0.70 & 0.80 & 2.36 & 1.83 & 0.21 & $\mathrm{I} .12$ & 1.83 \\
September & 0.62 & 0.82 & 2.01 & 2.09 & 0.04 & 1.21 & 1.28 \\
October & 0.62 & 0.31 & 2.31 & 3.01 & 0.20 & 1.20 & 2.29 \\
November & 0.93 & 0.33 & 2.32 & 2.80 & 0.18 & 1.12 & 1.98 \\
\hline
\end{tabular}

Table 3 Total Concentration, Mean \pm Standard Deviation, And Range of Heavy Metals $(\mathrm{Mg} / \mathrm{Kg})$, in Periwinkle

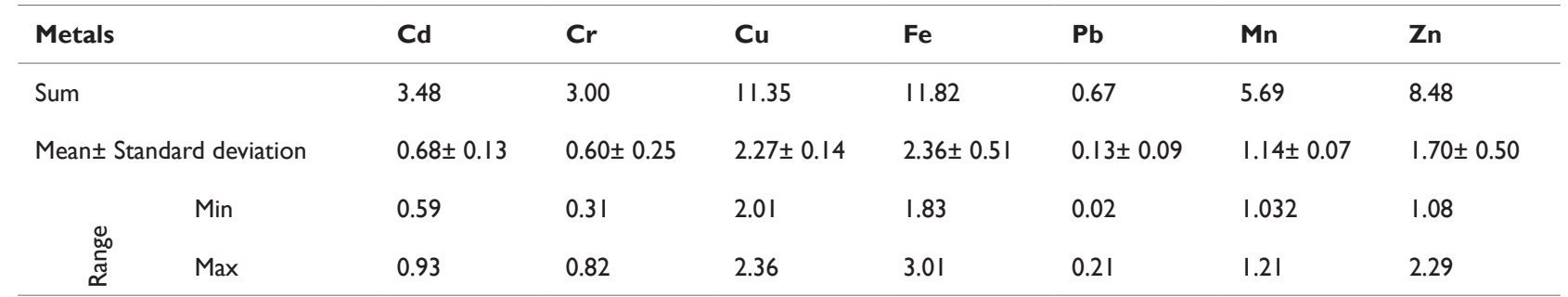


Table 4 Monthly total concentration of heavy metals determined $(\mathrm{mg} / \mathrm{kg})$ All values represent mean $\pm S D$ with ranges in periwinkle

\begin{tabular}{lllll}
\hline \multirow{2}{*}{ Months } & Total conc. & Mean \pm SD. & \multicolumn{2}{c}{ Range } \\
\hline July & 7.86 & $1.12 \pm 0.8 \mathrm{I}$ & 0.02 & 2.32 \\
August & 8.88 & $1.27 \pm 0.67$ & 0.21 & 2.36 \\
September & 8.10 & $1.16 \pm 0.73$ & 0.04 & 2.09 \\
October & 9.96 & $1.42 \pm 1.11$ & 0.20 & 3.01 \\
November & 9.68 & $1.38 \pm 1.00$ & 0.18 & 2.80
\end{tabular}

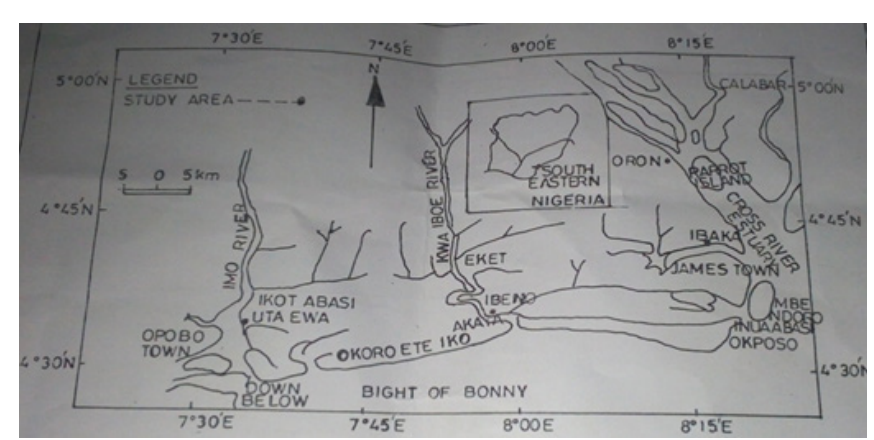

Figure I Map of Uta-ewa River and the tributary.

\section{Discussion}

The mean concentration of cadmium in periwinkle was $0.68 \pm 0.132 \mathrm{mg} / \mathrm{kg}$. The value was lower than that recorded by Abiaobo et al. ${ }^{10}$ on heavy metal concentration in shell and fin fish from Iko river estuary, southeastern Nigeria and higher than that recorded by Aderinola et al., ${ }^{11}$ who studied heavy metals in surface water, sediment, fish and periwinkle of lagos lagoon. The low concentration of cadmium in periwinkle from Uta-ewa creek may be attributed to the occupying of lower trophic niche of the organism with less abundance of food resources which could have influenced bioaccumulation from heavy metal effluents discharged by Aluminium Smelter Company into the creek Ekpo and Ukpong. From the study, the mean value of cadmium concentration recorded in periwinkle was higher than the recommended limit of $0.5 \mathrm{mg} / \mathrm{kg}$ for fish food. ${ }^{12,13}$ Cadmium is a byproduct of lead and zinc and is used in nickel-cadmium batteries, and ingestion of cadmium can cause vomiting, abdominal cramp and headache, Therefore, consumption of fishes which is concentrated with cadmium from Uta-Ewa can cause serious health hazards. ${ }^{10}$ The mean concentration of chromium was $0.60 \pm 0.26 \mathrm{mg} / \mathrm{kg}$, which was higher than that recorded value by Aderinola et al., ${ }^{14}$ who examined heavy metal deposits in surface water, sediment, fish and periwinkle in Lagos lagoon, although the value was lower than that recorded by Abiaobo et al., ${ }^{10}$ in shell and fin fish from Iko river estuary. The higher mean concentration of $\mathrm{Cr}$ in periwinkle from Uta-ewa creek could be attributed to the bottom dwelling and feeding habit of periwinkle, which swims in water and seldom get to the bottom sediment. This was higher than the maximum permissible limit of $0.003 \mathrm{mg} / \mathrm{kg}$ for periwinkle. ${ }^{12,13} \mathrm{Cr}$ compound are found in the environment due to erosion of $\mathrm{Cr}$-containing rocks. The high $\mathrm{Cr}$ concentration may owe to discharge of waste water from agriculture-related activities, domestic waste from various housing estate and ALSCON effluent discharged into the creek. $\mathrm{Cr}$ is also used for wood preservation and is very toxic when inhaled. It can cause asthma. Therefore, high concentration of chromium in periwinkle from Uta-Ewa river may cause serious health hazards.

The mean concentration of copper in periwinkle was $2.27 \pm 0.14 \mathrm{mg} /$ $\mathrm{kg}$. This value was higher than Eneji et al., ${ }^{15}$ who assessed heavy metals in fish and periwinkle from north-central Nigeria but, was lower than that obtained by Abiaobo et al., ${ }^{10}$ The concentration of copper in periwinkle in Uta-ewa creek could be attributed to domestic and anthropogenic activities such as oil exploration and refining, which can introduce this metal into the water body and eventually sediment from where fauna feed. Mean concentration of copper in periwinkle from Uta-ewa creek was lower than the permissible limit of $3.00 \mathrm{mg} /$ kg. ${ }^{12,13}$ Copper is one of the metals that is essential to human health. It combines with certain protein to produce enzymes that act as catalyst to make the body function and it is also necessary for the synthesis of hemoglobin. However, consumption of periwinkle which is copper concentrated from Uta-ewa Creek could pose health hazards. The mean concentration of iron in periwinkle was $2.36 \pm 0.51$. The value from this studies was lower than that of Aderinola et al., ${ }^{14}$ reported on heavy metal concentration in surface water, sediment, fish and periwinkle from Lagos Lagoon and that of Akinrotimi et al., ${ }^{16}$ who studied seasonal variation of heavy metals in selected sea foods from Buguma and Ekerekana creeks Niger Delta. The concentration of iron in periwinkle from Uta-ewa creek could be attributed to the fact that this metal is naturally abundant in Nigerian soils, where they are leached into the sediment of water bodies eventually where the fauna feed. ${ }^{17}$ The mean concentration of iron recorded was higher than the recommended standard limit of $0.5 \mathrm{mg} / \mathrm{kg}$ for periwinkle and fish. ${ }^{12,13}$ Iron is a necessary element in human diet and it plays significant role in metabolic processes. Thus, iron is an essential heavy metal; however, it has the tendency to become toxic when aquatic organisms from Uta-ewa creek are excessively consumed. The mean concentration of lead $(\mathrm{Pb})$ was $0.13 \pm 0.94 \mathrm{mg} / \mathrm{kg}$. The United States Environmental Protection Agency has classified lead as being potentially hazardous and toxic to most forms of life. ${ }^{18}$ Lead is toxic and has no significant biological functions. It shows its carcinogenic effects on aquatic biota and humans even at low exposures thus resulting in reproductive and development defects. This metal has been found to be responsible for quite a number of ailments such as chronic neurological disorders especially in fetuses and children. ${ }^{19}$ The concentration of $\mathrm{Pb}$ in the samples were lower than the maximum permissible limits by WHO and FEPA ${ }^{12,13}$ and therefore $\mathrm{Pb}$ may not pose serious health consequence to consumers at short term of exposure but could be in the long run, especially as it does not have any metabolic function. ${ }^{19}$

The mean concentration of manganese in periwinkle and fish were $0.13 \pm 0.07 \mathrm{mg} / \mathrm{kg}$ and $2.21 \pm 0.19 \mathrm{mg} / \mathrm{kg}$ respectively. This was lower than that recorded by Eneji et al. ${ }^{15}$ who studied bioaccumulation of heavy metals in fish organ around the North-central Nigeria as well as the report of Olowoyo 2011. Vales in their report was higher in fish than the standard limit of $0.4 \mathrm{mg} / \mathrm{kg}$ recommended for fishes but lower in periwinkle with $0.5 \mathrm{mg} / \mathrm{kg}$ recommended by FEPA and WHO. ${ }^{12,13}$ The concentration of Mn in Uta-ewa river was attributed to the physiological properties that maximizes absorption efficiency from the water. $\mathrm{Mn}$ is an essential micronutrient for plant and animals, and it is associated with iron deposits. However, it does not occur naturally as metal in aquatic ecosystem. Manganese results in severe skeletal and reproductive abnormalities in mammals. Nevertheless, ingestion of fishes from Uta-ewa Creek that is concentrated with manganese may pose serious health hazards. The mean concentration of Zinc was $1.70 \pm 0.50 \mathrm{mg} / \mathrm{kg}$, which was higher than that of Aderinola 
et al. ${ }^{14}$ who assessed heavy metals in surface water, sediment, fish and periwinkle from Lagos Lagoon, but lower than the values obtained by Eneji et al..$^{15}$ on bio-accumulation of heavy metals in fish and periwinkle organ from north-central Nigeria. The value obtained from this study is higher than the standard limit of $0.10 \mathrm{mg} / \mathrm{kg}$ for periwinkle. ${ }^{12,13}$ The concentration of zinc in periwinkle from Uta-ewa river could be attributed to land use activities such as agricultural system and effluent from residential and ALSCON area. Zinc is an essential trace metal for both plant and animals as it is necessary for embryo development as well as reproductive outputs. Its deficiency may cause retarded growth; therefore, high intakes of periwinkle which are $\mathrm{Zn}$ concentrated from Uta-ewa river can pose serious health hazards.

\section{Conclusion}

The study clearly indicated significant accumulation of heavy metals in periwinkle from Uta-ewa river. There were significant differences found in the accumulation levels of $\mathrm{Cd}, \mathrm{Cr}$ and $\mathrm{Mn}$ but none in other metals studied. Bioaccumulation of some of the metals in periwinkle was higher than the recommended maximum permissible limits of WHO and FEPA, showing that long term consumption of aquatic resources from Uta-Ewa Creek might be hazardous.

\section{Acknowledgments}

None.

\section{Funding}

None.

\section{Conflicts of interest}

The author declares that there are no conflicts of interest.

\section{References}

1. Khlifi R, Hamza-Chaffai A. Head and neck cancer due to heavy meta exposure via tobacco smoking and professional exposure, a review. Toxicol Appl Pharm. 2010;248(2):71-88.

2. World Health Organization. Hazardous Chemical in Human and Environmental Health. W.H.O. Geneva. Switzerland, 2000. 211 p.

3. MacFarlane GB, Burchettt MD. Cellular distribution of $\mathrm{Cu}, \mathrm{Pb}$, and $\mathrm{Zn}$ in the Grey Mangrove Avicemnia marina (Forsk.).Vierh Aquatic Botanic. 2000;68:45-59.

4. Oronsaye JAO, Wangboje OM, Oguzie FA. Trace metals in some benthic fishes of the Ikpobariver dam, Benin City, Nigeria; African Journal of Biotechnology. 2010;9(51):8860-8864.
5. APHA (American Public Health Association). Standard methods of the examination of water and wastewater. 19th edn. American Public Health Association, Washington DC. 2005;121- 226.

6. Alaa GM, Osman WK. Water Quality and heavy metal monitoring in water, sediments, and tissues of the African catfish Clariasgariepinus (Burchell, 1822) from the River Nile, Egypt. Journal of Environmental Protection. 2010;1(4):389-400.

7. Storelli MM, Storelli A, D'ddabbo R, et al. Trace elements in loggerhead turtles (Carettacaretta) from the eastern Mediterranean Sea: Overview and evaluation. Environmental Pollution. 2005;135(1):163-170.

8. Oguzie FA, Izevbigie EE. Heavy metals concentration in the organs of the silver Catfish, Chrysichthysnigrodigitatus(Lacèpéde) caught upstream of the Ikpoba river and the reservoir in Benin City. Bioscience Research Communications. 2009;21:189-197.

9. AOAC. The Association of Official Analytical Chemists. Official Methods of Analysis. 15th ed. Atomic Absorption Methods for Fish. Washington DC. 1990.190 p.

10. Abiaobo NO, Akpan II, Umana SI. Assessment of Heavy Metals Concentration in Shell and Fin Fish from Iko River Estuary, Southeastern Nigeria. Journal of Agriculture and Ecology Research International. 2017;12 (4):1-8.

11. Aderinola OJ, Clarke EO, Olarinmoye OM, et al. Heavy Metals in Surface Water, Sediments, Fish and Perwinkles of Lagos Lagoon. AmericanEurasian J Agric \& Environ Sci. 2009;5(5):609-617.

12. WHO (World Health Organization). Guidelines for drilling water quality (ii): Health Criteria and supporting information.vol.1, recommendations. World Health Organization Geneva, 1985. 130 p.

13. F.E.P.A. (Federal Environmental Protection Agency). Guidelines and Standards for Environmental Pollution Control in Nigeria. 2003;238 p.

14. Aderinola OJ, Clarke EO, Olarinmoye OM, et al. Heavy metals in surface, sediments, fish and periwinkle of Lagos Lagoon. Amer.-Euras. J Agric \& Environ Sci. 2009;5(5):609-617.

15. Eneji IS, Sha R, Annune PA. Environmental Monitoring and Assessment, Springer Publisher. 2011.

16. Akinrotimi OA. Effects of acute stress on haematological parameters of Tilapia guineensis. Int J Natl Appl Sci. 2009;5(4):338-343.

17. Ademoroti CMA. Environmental Chemistry and Toxicology. First edition, Foludex Press Limited, Ibadan. 1996. 80 p.

18. US Environmental Protection Agency. Methods for measuring the toxicity and bioaccumulation of sediment associated contaminants with fresh water invertebrates. USA. 1996.

19. World Health Organization WHO. Chromium, zinc, lead, in drinkingwater. Background document for preparation of WHO Guidelines for drinking-water quality. Geneva, (WHO/SDE/WSH/03.04/4). 2003. 